

A lec L. Miller, Jill H. Rathus og

Marsha M . Linehan:

\section{Dialectical behavior therapy with suicidal adolescents.}

Guilford 2007. ISBN 978-1-59385-383-9

\section{Bokanmeldelse v/A nne Brager-Larsen}

U ngdom med tilbakevendende suicidalog selvskadeproblematikk, lever vanskelige liv, og er en utfordring i behandlingsapparatet. DBT (Dialectical Behavior Therapy) bygger på kognitiv atferdsterapi, dialektisk og zen-filosofisk tenkning og er opprinnelig utviklet av M . Linehan (1993). DBT er den behandlingsmetoden som i kontrollerte studier har vist best effekt for unge selvmordstruede kvinner med borderline personlighetsforstyrrelse. Impul sivitet, problemer med regulering av emosjoner og mestring av forhold til andre mennesker samt høy forekomst av sel vskading og suicidal atferd preger denne pasientgruppen. Sentralt i behandlingen er arbeidet med å utvikle ferdigheter i à regul ere følel ser og atferd. Det har nå kommet egen versjon av DBT for ungdom utviklet av psykologene M iller, Rathus og Linehan, og denne har de beskrevet i boken Dialectical behavior therapy with suicidal adolescents.

I første del av boken gjennomgås risikofaktorer for suicidal og sel vskadende atferd hentet fra nyere forskning, da kunnskap om risikofaktorer er kritisk viktig for klinikere som arbeider med ungdommer som skader seg selv. I D BT forstås suicidalatferd - med eller uten suicidal hensikt - som lærte mestringsmetoder som pasienten bruker i en akutt emosjonell krise når ingen andre mestringsal ternativer ser ut til å være tilgjengelige. Suicidalatferden sees som en flukt fra ekstremt ubehagelige følelser eller omstendigheter, og suicid sees som den ultimate flukt fra problemer i livet. U t fra denne forståelsen betrakter man i DBT det som svært viktig å lære mer hensiktsmessig atferd som kan erstatte det dysfunksjonelle atferdsmønsteret.

I kapitlene 3-5 gjennomgår forfatterne kjerneaspektene ved DBT, slik som dialektiske perspektiv, biososial teori, spesifikke behandlingsmetoder, behandlingsstadier og -mål, samt integrering av aksept- og endringsstrategier. H ierarkiske behandlingsmål er rettesnorer for prioriteringer og fokus i behandlingen der livstruende atferd alltid har forrang i terapien fremfor andre temaer. Forfatterne gjennomgår også hvordan et DBT behandlingsprogram kan organiseres for å oppnå sentrale funksjoner som:

1) å fremme evne til mestring, 2) øke motivasjon for endring, 3) sikre generalisering av nye mestringsferdigheter, 4) fremme terapeutens evner og motivasjon for effektiv behandling, og 5) strukturere miljøet rundt ungdommen slik at det støtter opp om ungdommens (og terapeutens) arbeid og mestring.

DBT ser på suicidalatferd og annen atferd assosiert med borderline personligh etsforstyrrelse som et resultat av emosjonell reguleringssvikt. Pasienten har ofte en enteneller-tenkning som bidrar til å opprettholde den dysfunksjonelle atferden. Slik polarisert virkelighetsforståelse kan betraktesi en større sammenheng som dialektiske dilemmaer og boken beskriver seks varianter av disse, hvorav tre som er spesifikke for ungdommer og deres familier. Det overordnede målet er å hjelpe ungdommene og familiene til å endre deres polariserte atferdsmønstre, og finne en gyllen middelvei i tanker, følelser og handling.

Boken presenterer anbefalte screeningsverktøy til hjelp ved vurdering av suicidrisiko, vurdering av borderline personlighetsforstyrrel se og assosierte problemer, og for screening av generell psykopatologi og familiefungering. Etter å ha vurdert om klienten er i målgruppen for DBT, starter en forbereden de fase (pretreatment) der ungdom og foresatte blir orientert om DBT. Forpliktelse er et sentralt begrep både i den forberedende fasen og $\mathrm{i}$ behandlingen generelt. U ngdommer med emosjonelle vansker og trekk fra ustabil personlighetsforstyrrelse dropper lett ut av behandling, og dersom ungdommene ikke møter opp til behandlingen er det naturligvis nokså umulig å gi hjelp. Et sentralt mål tidlig i behandlingen er derfor å etablere en god terapeutisk allianse med ungdommen, noe som både er avgjøren de og vanskelig, fordi mange ungdommer som kommer til behandling i første omgang ikke selv ser behovet for slik hjelp.

Forfatterne beskriver steg for steg hvordan individualterapi utføres etter D BTprinsipper. $\mathrm{H}$ er blir leseren kjent med dagbokskortet som ungdommene skal fylle ut daglig og ha med ferdig utfylt til hver time. Dagbokskortet er styrende for hvilket fokus den enkelte individual terapisesjon skal ha. Videre er tilbud om familieterapi en tilpasning ved DBT for ungdom, og finnes ikke i den originale DBT-versjonen for voksne (Linehan, 1993a). G runnen er at de fleste ungdommene fremdeles bor hjemme i de samme omgivel ser som har vært med på å forsterke den dysfunksjonelle atferden over mange år. A ha med sentrale omsorgspersoner i behandlingen øker sannsynligheten for generalisering av endret atferd og samtidig mulighet for at endringene blir varige.
$\AA$ endre godt innlært atferd og kommunikasjon er vanskelig. Innlæring av nye ferdigheter krever oppmerksomt nærvær til egen atferd, følel ser og tanker. U ngdom og foresatte går gjennom et 16 ukers ferdighetstreningsprogram. Fem ferdighetsmoduler læres: oppmerksomt nærvær (mindfulness), stresstoleranse, mellommenneskelige ferdigheter, emosjonsregulering og den gylne middelvei. Sistnevnte modul presenteres i sin helhet i et av bokens appendixer, og ble utviklet spesifikt for DBT for ungdom. I et annet appendix presenteres en samling oppmerksomt nærværøvelser spesifikt tilpasset for ungdom, og som forfatterne selv anbefaler og bruker i egen praksis. $G$ jennom dette lærer ungdommene å være i større grad til stede i livet sitt her og nå, enten det er smertefullt eller ikke, stressende eller rolig. A akseptere at livet også inneholder smerte, gjør en bedre i stand til å tåle nettopp smerten - og i aksept ligger mulighetene for endring. Samtidig vil oppmerksomhetsøvelsene bidra til at ungdommene blir bedre i stand til tidlig å oppdage og ta hensyn til egne emosjonelle reaksjoner. For å få kontroll over ustabile følel ser jobbes det med å observere, registrere og delta, på en ikke-dømmende måte, både i forhold til egne følelser, tanker og handlinger, men også overfor andre mennesker.

Etter min vurdering er boken lettlest og velskrevet, forutsigbart disponert i hovedtemaer og undertemaer med en enkel og oversiktlig innholdsfortegnelse. Boken er også fullspekket med konkrete eksempler og oversiktstabeller. Det viktigste er kanskje at forfatterne gir konkrete råd og retningslinjer til terapeuten - ikke minst om hvordan mestre utfordrende følel ser som vekkes i arbeidet med disse ungdommene. Leseren forstår raskt at boken er noe mer enn et sett med ferdigheter og teknikker - det er en måte å forstå og konseptual isere menneskelig atferd på. DBT byr på ny forståel se og nytt språk i møte med klienter som fyller kriteriene for borderline personligh etsforstyrrelse - fritt for fordommer og forutinntatte holdninger som "splitting" og "manipulering" - og det krever sin terapeut!

Boken anbefales på det varmeste, og er relevant for terapeuter som jobber med ungdom generelt og ansees som et viktig bidrag til forebygging av suicidalitet og selvskading hos ungdom. 